\title{
Multimedia Courseware Design Strategies Based on the Theory of Multiple Intelligences
}

\author{
Jinrong Zhou \\ Information and Management Engineering Department \\ Nanchong Vocational and Technical College \\ Nanchong, Sichuan, China 637131
}

\begin{abstract}
With the rise and development of the multimedia teaching, how to improve the effectiveness of the courseware has become the focus of teachers in their courseware design, while the development of the four kinds of intelligent features, such as diversification, differentiation, creativity and development, advocated by the theory of multiple intelligences, is consistent with the philosophy of multimedia courseware design. By applying the four features, we can make the multimedia design meet the students' intelligent needs, promote the individual acquisition of students and improve the teaching effect.
\end{abstract}

Keywords-theory of multiple intelligences; multimedia courseware; design strategies

\section{INTRODUCTION}

Multimedia technology has been popular, which makes teachers easily organize their courseware with the teaching materials in various forms, such as text, graphics, animation, sound, video and so on, and put the teaching materials on the projection screen for teaching. Today, more and more teachers apply courseware to assist their teaching and this method has become the mainstream trend in classroom teaching. However, some teachers depend on multimedia technology in a excessive degree when they make their courseware, and neglect of the teaching design of courseware, and further they become the courseware into a amplified textbook, change the past simple "mouth teaching" as traditional classroom teaching type into the current "electric teaching", so that they can not achieve the desired effect of teaching in application of multimedia courseware. Therefore, we must take effective strategy for the design of courseware, while the theory of multiple intelligences is a new concept of intelligence and it puts forward the type of human thinking and understanding the world is diversified, and proposes different explanation and elaboration of traditional teaching design, so it has very important impact in the teaching reform and provides a new supporting points and new basis for the courseware design.

\section{THE THEORY OF MULTIPLE INTELLIGENCES AND ITS CONNOTATIONS}

The theory of multi-Intelligences [1] (referred to MI for short) is first proposed by the American educational psychologist Harvard Gardner (1983) after he made study on human brain and intelligence of different objects. He redefined the intelligence from three viewpoints, namely intelligence is an ability to solve problems and create consciousness in the single or multi-cultural environment, an ability of people to be able to face problems and solve problems in their life, and an ability of people to continuously accumulate new knowledge when they find problems and solve problems. Every normal one more or less has linguistic intelligence, mathematical logical intelligence, spatial intelligence, physical intelligence, musical intelligence, interpersonal intelligence, self-awareness intelligence, naturalistic intelligence. The theory of multiple intelligences emphasizes that various abilities exist not in an integrated form, but in a relatively independent form, and these abilities have the basic characteristics of pluralism, diversity, creativity and development. [2]

According to this theory, all students have their preponderant intelligence field and intellectual type, and this view goes beyond the traditional single intelligence theory, enlightens teachers to further improve the traditional teaching design and provide a variety of instructional design ideas and give teaching with more space of flexible application. For multimedia courseware, we can refer to the theory of multiple intelligences to design courseware and create circumstances according to students 'needs, interests and potential, and try not to neglect any student. Especially in the process of courseware teaching, we should pay attention to the cultivation of students' innovative spirit and practical ability, fully develop student's intellectual advantage and promote students' personality development.

\section{The COMmon Problems In Multimedia COURSEWARE DESIGN}

Multimedia teaching is also known as computer multimedia teaching, means that the teaching information is presented in a performance way of multimedia (including text, images, photographs, sounds, animations and videos) in the teaching process, so as to achieve the purpose of teaching assistance.

At present, the application of multimedia teaching has gradually got popular in the universities, middle schools and elementary schools, and the advantages of multimedia teaching are highlighted mainly in two aspects: first, multimedia can present the teaching content in a visible, 
visual and vivid way through human senses (sight, hearing, touch); second, multimedia can hold a wealth of information, and can demonstrate and simulate some teaching situation, to make the classroom more rich. These advantages make teachers more and more like the application of multimedia courseware in their teaching, and many teachers have also achieved some results in their teaching. However, many teachers ignored the leading role of teachers in their use of multimedia courseware and their teaching process, which makes the teaching effect get bitching from many scholars.

At present, many scholars in China have studied the effect of multimedia teaching, and some of them have pointed out the negative effect of multimedia courseware for teaching, for instance, multimedia teaching changed only from the previous rigid "textbook scripted" into the current "screen scripted"; multimedia courseware became purely the electronic textbooks and students became the viewers of electronic textbooks. We can find from these descriptions, the current application of multimedia teaching has no ideal effect, and in the final analysis, the teachers are short of courseware design strategy in the production and use of multimedia courseware, and these problems are probably as follows:

\section{A. Unreasonable Arrangement of Multimedia Courseware Content}

Many teachers always directly put the contents of textbooks into the courseware in their production of courseware, and show too much text on one page, with dense characters but without primary and secondary division, which affects the menu appearance of the courseware and impacts students' information acceptance.

\section{B. Inappositely Picture Theme of Multimedia Courseware}

Picture is a necessary element in the production of multimedia courseware, but pictures are inserted in every page of some courseware, while some pictures have nothing to do with the lectures, so such courseware may often confuse its subject of information.

\section{Multimedia in Lack of Media Skills}

Sound, video, animation and other similar materials make multimedia courseware diversified and make it achieve the simulation of teaching situations, making the teaching content more substantial. However, if these materials are not processed properly, they can not render the situations in the courseware, and not create a realistic scene for students.

\section{Multimedia in Lack of Interactive Feature}

Interaction is an important part in the teaching process, including direct exchange between teachers and students and indirect exchange by means of medium, and no matter how the interactive carrier is always people. An important feature of multimedia courseware different from traditional media is its interaction, while many teachers ignored this feature in their design of multimedia courseware.

\section{E. Improper Color Arrangement of Multimedia}

In the production of multimedia courseware, most teachers make random color arrangement for courseware according to their own preferences, without consideration in combination with learning objects and content, making some courseware colors too much or inappropriate, which not only may disperse the students' attention but also may affect the teaching effect.

\section{The Multimedia Courseware Design Strategy UNDER THE GUIDANCE OF THE THEORY OF MULTIPLE INTELLIGENCES}

The production of multimedia Courseware is not random, and a successful multimedia courseware must have good guidance ideology. The theory of Multiple Intelligences has its basic features like difference, diversity, creativity and development, which meets the needs of classroom teaching, and if applied to multimedia courseware, can improve students' comprehension and enhance the teaching effectiveness.

\section{A. Application of the Differences of the Theory of Multiple Intelligences in Courseware Design}

The theory of multiple intelligences emphasizes students' intelligence differences, and it thinks that everyone has seven independent intelligences, but everyone's intelligence has different characteristics as these intelligences are combined in different ways and in different degrees under the impact and constraints of different environments and education. The characteristic of difference certainly affirms the different abilities of students, so it is required for teachers to depend on students' demand to make analysis of learners to understand the intelligent difference between students and to regard students' intelligent advantages to select questions and review questions according to the emphasis of teaching materials and the students' intelligent ability in the courseware design, so as to endow the courseware with vitality and make the courseware vivid, and future really attract the attention of students in the classroom, cultivate students' interest in learning, change "let me learn" into "I want to learn", change "focusing on results " into "focusing on process ", change " learn" into " know how to learn". For example, in teaching, what is not suitable for presentation by courseware and what need the assistance of multimedia for teaching. Meanwhile, we must consider the principle of effectiveness, and when we can achieve good teaching effect with the conventional teaching methods, we can not use multimedia courseware, and on the contrary, when we can not render and clearly explain the problems with the traditional teaching methods, we should use multimedia courseware to improve the classroom efficiency.

\section{B. The Application of Diversity of Theory of Multiple Intelligences in Courseware Design}

The theory of multiple intelligences emphasizes the diversity of students' intelligence, and it thinks that intelligence is the ability of a kind of or a group of people to solve problems, or the ability to make one or various 
valuable inventions. In addition to the two types of linguistic intelligence and logical - logical-mathematical intelligence, people also have seven other intelligences, including visualspatial intelligence, musical-rhythmic intelligence, physicaloperational intelligence, interpersonal intelligence, insightintrospective intelligence, naturalist intelligence and existential intelligence. Therefore, teachers shall understand the students' deference in intelligence and their intellectual advantages and weaknesses when they design the courseware, and especially pay attention to material collection and sorting, and use the wealth of materials to build students' learning activities in accordance with their intellectual development, design diverse expression form and contextualized presentation way, to meet the different cognitive styles of students, and to enable students to enjoy the fun of learning. For example, when processing the text, images, sound, video and animation required in the courseware, we should make a key analysis on students' intellectual abilities and choose the appropriate materials for students' intelligence and teaching topic.

\section{The Application of Creativity of the Theory of Multiple Intelligences in Courseware Design}

The theory of multiple intelligences emphasizes the creativity of students' intelligence, while the main goal of modern education is to train a large number of creative or innovative talents in line with the development needs of the times. To cultivate students creative awareness and to make students always keep curiosity, not satisfy with the existing knowledge and hold analytical and critical attitude for popular traditional idea and ready-made conclusions, teachers must contain a certain interaction design in their courseware production, by which the interaction between teacher and student and between students is reflected, so that creative thinking will produce in the classroom exchange, and the learning results of students but also the change and development of learning activities are concerned about in the teaching. For example, we can insert exercises, test evaluation and other interactive design in the courseware to enhance students' interest in learning and the courseware effectiveness.

\section{The Application of Development of the Theory of Multiple Intelligences in Courseware Design}

The theory of Multiple Intelligences emphasizes the development of students' intelligence, and the degree of multiple intelligence depends on the development, while helping students develop their potential ability is teacher's duty. This requires teachers shall create circumstances in their design of courseware to bring students in a simulated circumstance of teaching, so that we can make students learn in the process of practice and free research and make them better apply and develop their intelligences.

\section{CONCLUSION}

Based on the theory of multiple intelligences, the strategy to produce Multimedia Courseware is to design courseware with student's intelligence as the center. This is helpful for mobilizing students' enthusiasm and enhancing the teaching effectiveness of classroom.

\section{REFERENCES}

[1] [US] HarvardGardner.Framesof Mind [M] .New York: BasicBooksInc, 1983.

[2] [US] Howard •Gardner. Multiple Intelligences [M] Beijing: Xinhua Publishing House, 2004.

[3] Cheng Jing. Discussion on Multiple Teaching Appraisal System in Teaching of Law in Colleges and Universities [J] knowledge economy, 2015,08: 134.

[4] Li Yi. Study on Secondary Vocational Students Management under the Guidance of the Theory of Multiple Intelligences [J] textile and apparel education, 2015,01: 35-37.

[5] Sun Lei. Study on Diversified College English Classroom Teaching Mode - based on the "Theory of Multiple Intelligences" [J] Journal of Xi'an Aeronautical College, 2015,02: 85-88.

[6] Wang Zhonghai, Liu Xiaofei. Study on College Teaching and Human Resources Management of Scientific Research in the Perspective of Multiple Intelligences [J]. Human Resource Management, 2015,04: 107-108.

[7] Ren Yimei, Cui Huimin. View on Vocational School Teachers' View about Student under the Theory of Multiple Intelligence [J] knowledge Guide, 2015,02: 27.

[8] Zhu Yan. Study on Vocational Education Project Teaching based on the Theory of Multiple Intelligences[J]. Communication of Vocational Education, 2015,07: 63-66.

[9] Zhang Hui, Zhang Jinbo. Study on College Foreign Language Teaching Practice under the guidance of IT [J]. Journal of Nanjing Industry and Vocational Technology College, 2015, 01: 65-68.

[10] Li Jing, Li Xinfang, Qiu Jingling. Discussion on Problem-based Exploratory Learning in the Viewpoint of the Theory of Multiple Intelligence $[\mathrm{J}]$. Chinese Education Technology and Equipment, 2015,06: 91-92.

[11] Wu Chenggang. Discussion and Analysis on Vocational students achievement motivation Awakening in the Perspective of the Multiple Intelligence [J]. Journal of Beijing Vocational College of Agriculture, 2015,02: 87-91.

[12] Li Xiating. Discussion on the Way of Vocational Students' Creativity Training of Computer Major under the Theory of Multiple Intelligence [J]. Asia-Pacific Education, 2015,07: 140.

[13] Sun Zhili. Education Management of "Problem Students" in the Perspective of Multiple Intelligence [J]. Journal of Fuyang Teachers College (Social Science Edition), 2015,02: 128-130.

[14] Liu Weiwei. Study on Interactive Multimedia Courseware Design and Application [D]. Shandong Normal University, 2008.

[15] Xiang Dongmei. Research of Multimedia Teaching Information Characterization Design [D]. Southwest University, 2008.

[16] Geng Jianmin. Study on Multimedia Courseware Design based on Classroom Teaching[J]. China Educational Technology, 2011,06: 8588.

[17] Zhang Boyi, Li Fang. Visual Information Transition Design Strategies of Multimedia Courseware [J]. Journal of Changsha Railway University (Social Science Edition), 2008,04: 145-146 + 153 